《解 説》

\title{
カチオン電着治具のはく離
}

Stripping of Fixtures of Cationic Electsodepositied Paints

\section{塗装治具の溶剤型塗料はく離剤によるはく離と特にカチオン電着塗料 が付着した治具を短時間ではく離できる溶融塩について紹介する。}

\section{斎 藤 勇 郎* \\ Isao Saito}

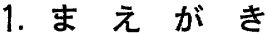

\section{塗装はく離の方法には}

物理的方法（ショットブラストなど）

化学的方法

熱分解法（流動床または炬による）

があり，委た場合によっては焼却によるはく 離を行うこともある。叙装治具のはく離につ いてい竞ば，はく離によって材料が荒れない こと，材質が変らないこと，形状変形が起ら ないこと，拈よび治其の使用寿命を短くしな いことも李た一緒汇要求される。ここでは化 学的はく離法がぞのように発展し現在どのよ らなレベルになで到達しているか，特にカチ オン電着塗装の治具の溶融塩によるはく離を 中心に述べたい。

\section{2. 塗料はく離剤}

\section{2-1 概説}

*パーカー商事(株) 取締役

于103 東京都中央区日本橋2-16-11

雨 03 (273) 7461
化学的に塗膜をはく離するために利用され る方法は基本的にはアルカリによる簽化作用 と溶剤による溶解と浸透作用とである。初期 の塗料では単純にアルカリか溶剤を用いるこ とで十分目的が達せられたが，その後次々に 出現した合成樹脂塗料は耐薬品性が向上し塗 膜の化学構造が一層強固になって来たため, これ迄のはく離剂では仲々とれ難くなって来 た。これに対応するためはく離剤は多くの改 良が加光られつつ今日に至っている。新しい 塗料が出現するたびに新しいはく離剤を研究 するところ迄現在はなっている。

\section{2-2 電着塗料治具のはく離}

(1)アルカリ型はく離

アルカリ十水溶性溶剤処方のはく離剤がア ニオン電着塗料のはく離に利用されている。 はく離時間は短く, 事実自動はく離ラインに 組入れられている。

(2)溶剂型はく離剤

溶剤型はく離剤もまたアニオン電着塗料の はく離にはよく使われている。この場合，溶

* Parker Commercial Co., Ltd.

16-11 Nihonbashi 2cho-me, Chuo-ku, Tokyo 103: 
鼡十有機アルカリ，または溶剤十有機酸が基 本的な処方となっている。自動はく離ライン よりは,むしろバッチ式はく離に利用される ことが多い。比較的小型の槽でかつ常温で使 用出来るからである。な祘，現在では，かつ て有効な処方であったフェノールやクロメー トを含む溶剤型はく離斉は公害規制の面から ほとんど使われなくなっている。

(3)カチオン電着塗料はく離への挑戦 カチオン塗料は従来の塗料系 (アニオン㙦 料を含む）と異なり，透水性の小さい，強じ んな塗膜を形成するため，溶剤十アルカリ系 はく離剤では，十分なはく離が出来ず，浸透 性, 膨潤性の良好な溶剂十有機酸の組み合せ で試作開発されつつあが，槽及び治具自身 を耐酸性のステンレス材料でつくらねばなら ぬこと, 自動はく離に適用するにははく離所 要時間が長いこと，及び細分化はく離しない ため水洗時の残存塗膜払落しが容易でないこ となどのため自動はく離ラインへの実用化に は問題がある。

\section{3. 溶融塩はく離法}

\section{3-1 概説}

昔から金属の臨入れや窒化その他の熱処理 に溶融塩が使用されていることはよく知られ ている。溶融塩とは無機の塩類を加熱してそ の融点以上の温度で液体の状態を保持してい るもののことないう。この溶融塩が日本でも 20 年程前から水溶液や溶丳で困難な金属洗浄 に利用される様になった。溶融塩ではその化 学反応が温度によって一段と促進されるため これ迄出来なかった仕事も短時間で完結する ようになる。例：(1)酸化性アルカリ塩浴によ るステンレス鋼のデスケーリング, (2)電解ア ルカリ塩浴による鋳砂の溶解（条件をかえる ことによって鋳鉄組織の遊離グラファイトを 除去することが出来る)。塗装はく離には酸
化性アルカリ溶融塩を使用する。溶融塩によ る塗膜はく離は水溶液系, 溶剤系による膨 潤，浸透，溶解の作用亡異なり，塗膜の酸化 熱分解反心によるため，塩浴中で樹脂は完全 に無機化されてしまう。またこのことから溶 融塩による塗料はく離では塗料が何であるか は全く問題にならない。はく離時間も十分に 速く $1 \mathrm{~cm}$ 位の塗膜厚でも 5 分〜 10分で完全 に除去することが出来る。

\section{3-2 塗料はく離溶融塩の化学}

(1)化学反応

ここで使用される溶融塩は酸化性アルカリ 塩浴であってその融点は約 $290^{\circ} \mathrm{C}$, 処理温度 範囲は $460^{\circ} \mathrm{C} \sim 480^{\circ} \mathrm{C}$ である。

塗料はく離の反応は次式で示すことが出来 る。

(1)樹脂 $(\mathrm{C}, \mathrm{H}, \mathrm{O})$ +酸化剤 $\rightarrow \mathrm{H}_{2} \mathrm{O}$

(3)水 $\left(\mathrm{H}_{2} \mathrm{O}\right)$ は水蒸気として系外出る。

(4)顔料（金属酸化物）は溶融塩に不溶であ り沈殿する。

(2)組成の維持

上記 (2) 式によって示される炭酸ソーダ $\left(\mathrm{Na}_{2} \mathrm{CO}_{3}\right)$ が系内に蓄積することは好ましい ことではない。その理由は炭酸ソーダが溶融 塩の塗装はく離反応に全く関与しない成分で あり重要な善柄は溶融塩の粘度を增大させ る。一般金属洗浄に使用される溶融塩の粘度 は本来非常に低いものである。（作業温度に 於㲿る溶融塩粘度は大抵の場合水のとれと同 程度になっている)。この溶融塩系湠酸り 一ダの量が段々増兄て行き $20 \%$ を越えると急 激に溶液粘度が高くなりそのま使用して行 くと遂には使用不可能となる。

そのため, 系内の炭酸ソーダ量を適度に抑 え過唾の炭酸ソーダは系外に沈殿するような 塩浴組成にする事で塩浴は更新することなく 何年でも連続して使用することが可能になっ ている。 


\section{4}

(3)金属への作用

塗料をはく離すべき金属製治具すまた塩浴 の化学作用，熱作用を受ける。治其は大抵の 場合鋼でつくられ，鋼は酸化剂の作用により 酸化されるがアルカリの影響は受けにくいの で洗浄された治具は均一な薄い酸化皮膜で特 拉わて出てくる。

溶融塩による塗料はく離温度は前記のよう に $460 \sim 480^{\circ} \mathrm{C}$ あ゙り鋼の変態点をはるかに下 超る温度であるので一般的に治具の変形ない 乙軟化は起らない。

\section{3-3 塗料はく離塩浴設備}

塗膜の溶融塩のはく離装置の開発は前記し たステンレスのデスケリングや電解アルカリ の鋳砂の溶解等の技術壱後述する塗膜のはく 離により発生する $\mathrm{Na}_{2} \mathrm{CO}_{3}$ スラッジの回収な どの努力によって，長期間安全に作業が出来 るような統合技術が確立された。

塗料はく離用塩浴槽の構成因子を図 1 に示 5。

\section{(1)加熱}

槽を直接加熱することはこの場合採用して はならない。一般に金属洗浄用溶融塩では永 年塩浴組成を維持するために洗浄反応生成物 は系外にスラッジとして沈殿回収させねばな らないが，もし塩浴槽を外側から直接加熱す れば底部に堆積したスラッジにより熱伀導を 阻害し, 底板がスーパヒートされ槽底がだれ， 槽は数ケ月しか持たない。

従ってこの種塩浴の加熱は浸せさ加熱管に よって行なわなければならず，多くの場合ガ ス燃焼浸せき管を用いる。電熱式加熱管の使 用も可能である。

加熱管からの伝熱は自然対流による場合も あるが，塗装はく離浴のようなスラッジ発生 量の多い場合にはかく拌機を以って強制対流 させることが望ましい。

(2)かく挥

加熱管の伝熱を助けるだけでなく次に述べ
るスラッジの回収にはかく拌は欠くことの出 来ない操作である。

(3)スラッジの回収

先きに述べた塩浴組成維持のため，不溶解 成分として塩浴から沈殿した炭酸ソーダや金 属酸化物は静置して底からスラッジとして引 上げることる出来るが，これら不溶解成分粒 子をかく拌によって常に液中に䀣濁させ槽内 のスラッジ沈殿室に液の一部を呼达むことに よりそこでスラッジとして沈殿させ作業には 影響せず，別個にスラッジを排除することが 最近では出来るようになった。

\section{3-4 工程および保守作業}

\section{(1)工程}

自動はく離設備ならばチェンコンベアによ って，バッチ式設備ならばホイストによって はく離する治具密搬送する。

塩浴によってはく離する時間は付着塗膜厚 によって15秒から数分の間である。

はく離した治具は水洗で塩類を除去する。 溶融塩は水によく溶け，自動ラインではスプ レイ法，バッチ式では浸せき法による水洗が 行われている。

(2)保守作業

塩浴の保守は(1)スラッジの排除と(2)塩浴剤 の補給を行わなければならないが，化学分析 による浴の管理は実務上しなくてもよい汪ど 安定している。

\section{3-5 カチオン電着治具はく離の実例}

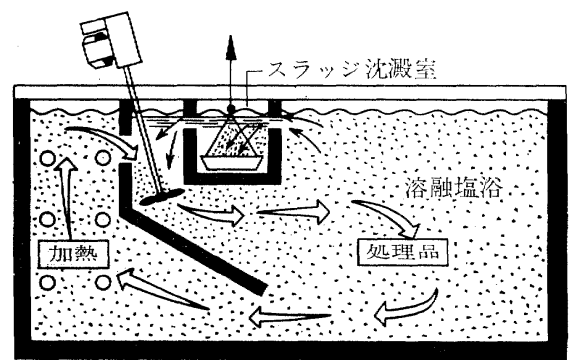

図 1 塗装はく離塩浴槽 
(1)自動はく離設備

図 2 はカチオン電着治具がチェンコンベア によって移送されながら自動的にはく離され る設備を示す。治具の塩浴に浸せきする時間 は30秒と設計され，水洗はスプレイであるが 潅ぎの完全のため二段階水洗を行っている。

(2)バッチ式はく離設備

バッチ式はく離設備の一例を示す。

バスケットに 25 本の治具を入れホイストで 塩浴槽から水洗槽へ移送する型の設備であ る。塩浴槽寸法は内寸 $1,800 \mathrm{~mm}$ 長 $\times 1,348$ $\mathrm{mm}$ 幅 $\times 1,500 \mathrm{~mm}$ 深, 水洗槽は $1,800 \mathrm{~mm}$ 長 $\times 900 \mathrm{~mm}$ 幅 $\times 1,500 \mathrm{~mm}$ 深の寸法で山り，両 槽は共通のフードで括おわれている。フード には前後に扉がつき，フード前面には浸せき 監視のためガラス空をつけてめる。この装置 で一日10hr の作業で 3,000 本の治具が処理出 来る。塩浴槽浸せさ時間は 1 分，水洗槽浸せ さ時間は 1 分としている。

バスケットは手動でも自動搬送でも可能で ある。

\section{3-6 必要な公害処理}

(1)排水処理

塩浴ではく離した治具をすすぐ水洗槽か らの排水は処理して排出しなければならな W。

溶融塩とれ自身が無機の塩類であることと 先きにも述べたようにこの方法は酸化熱分解 による万法であるため，樹脂は塩浴中では完 全に無機化されるので水洗槽排水には全く BOD 成分は含まれない。

水洗槽水質はまずアルカリ性であるので， 酸による中和処理をしなければならない。

次济料成分から来る金属酸化物はアルカ リ水質では大部分が不溶性であるので沈降分 離法で中和処理の前もしくは後で分離出来 る。

もし含クロム塗料をはく離する場合に限り 六価クロムが水洗水中に溶出するので，この 場合には中和処理前にあらかじめ還元処理を 行わなければならない。

(2)排気処理

電着塗装治具をはく離するような場合には 塗膜厚が極めて薄くすべて塩浴中で反応しガ スをたは煙の発生はなく特に排気処理の必要 はない。

しかし付着塗膜厚が厚くなるにつれ，液面 での反応・泡立らや液面上での然焼を伴い白 恓を発生するので，この場合にはバグフィル タによって白煙微粒子没捕捉するかアフター バーナーによって焼却処理することが必要と なる。

\section{4.あとがき}

電着塗装治具のはく離に焦点をあて, 塗料 はく離剤が塗料の開発とともに常に新しい処 方で対応して行かなければならないこと，お よび最近のカチオン塗料の出現に関連して溶 融塩による塗膜のはく離法と設備についてや や詳しく解説した。

これらのことは電着塗料に限

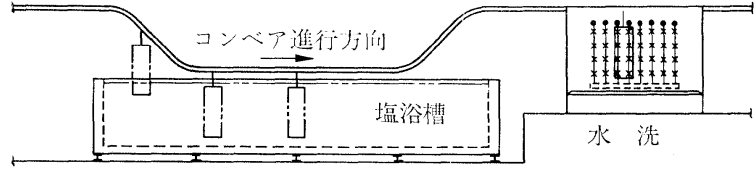

図 2 カチオン電着治具の自動はく離装置 らず，粉体塗料にもまた吹付塗 料にも応用出来ることであるの で,この稿がこれらのことに深 い関心を抱いている諸兄の参考 になれば甚だ幸いである。 